\title{
Redevelopment of the cultural heritage object (the case of the "Nurov's Estate")
}

\author{
Marina Bareicheva*, Ekaterina Kubina, and Liudmila Daineko \\ Ural Federal University, Institute of Economics and Management, 620002 Ekaterinburg, Russia
}

\begin{abstract}
The problem of redevelopment of cultural heritage sites is relevant and in demand all over the world, because such spaces carry the history and spirit of not only a particular place, but of an entire city. Many international and Russian researchers note that the revitalization and development of such sites will help to preserve the history and heritage of the city. In addition, there are many examples of the successful implementation of redevelopment projects and the creation of relevant and popular spaces on their territory. In this article we consider the project for the redevelopment of the Nurov Estate ensemble, located in Ekaterinburg (Russia). The project was carried out in cooperation with the owner of the object (development company) and is based on the concept of Art-cluster. For this project were calculated and considered indicators of commercial efficiency of projects.
\end{abstract}

\section{Introduction}

Many Russian cities are famous and proud of their rich history. Architectural evidence of Russia's significant historical periods are ancient buildings of cultural heritage. However, each year more and more funds are required to maintain and preserve the historical appearance and fill monuments of architecture. There is a certain degradation of objects of cultural potential of Russian cities [1]. The high cost of restoration and the low level of social responsibility of citizens for the preservation of national history and culture leads to a redistribution of priorities of developers in favor of new construction.

In the context of these trends, the authors propose to consider possible options for the actual redevelopment of cultural heritage objects. Creation of original, modern points of attraction on its areas, preserving their historical value and increasing both their economic and social effects for the citizens on the example of Ekaterinburg.

To begin with, let us define what is the degradation of cultural architectural heritage. The term covers not only the aesthetic function and the actual destruction of objects, but also the loss of basic functions and meaning for citizens. Renovation of an object, then, requires not only the restoration of its appearance, but also the actualization of its new functions, taking into account its past, present, and future prospects. It is necessary to create a point of attraction on the basis of existing needs in society [1].

* Corresponding author: bareicheva.m@yandex.ru 


\section{Research Methodology}

The same opinion is held by many researchers of the problem of the degradation of cultural heritage.

Turskis et al. note that each country has a large number of registered objects of cultural heritage in need of restoration. The authors created a hybrid model to rank them according to the cost of work. This development will be useful in the selection and development of redevelopment projects [2].

Kyriazi in his works considers one of the modern methods of solving the issue of cultural heritage preservation - facadism, when only the outer facade of the historic building remains authentic. The author touches on the relevance of this practice, the legality from the point of view of legislation, as well as gives recommendations for optimal solutions for the conservation of cultural heritage [3].

Maio examines the problem of preservation of historic buildings in Portugal. Here UCH were demolished for the construction of new modern facilities. The author notes that such actions destroy the historical and cultural center of the city. Therefore, the author talks about the need to raise awareness of all stakeholders in the possibilities of redevelopment. The 1998 database of the Regional Secretariat of Housing and Equipment was reviewed and analyzed again. As a result, the economic outlook for $\mathrm{UCH}$ asset renovation in Portugal was investigated, obtaining new repair cost functions that can be used to support action plans and develop risk reduction strategies [4].

Foster et al. in their study looked at the European experience. They also talked about the fact that cultural heritage buildings are part of the urban landscape of Europe, embodying the values of circular economy and sustainability. In addition, the renovation and adaptation of such objects for reuse can be considered more environmentally friendly than constructing a new building (less materials needed, reduced construction and demolition waste and greenhouse gas emissions, etc.). In their study, the authors introduce a new composite indicator called Circular City Adaptive Reuse of Cultural Heritage Index [5,6]. It is a systematic method for characterizing the investment opportunities of cultural heritage sites. In addition, renovation supports the circular economy goals of the 2019 European Green Agreement and the 2020 Building Renovation Wave Strategy [6,7,8].

In their work, Macek et al. consider the renovation of cultural heritage sites in terms of cost optimization. In addition to traditional procedures and methods applied to new modern objects, it is necessary to take into account many of the peculiarities and differences. As a result, in order to establish the costs of restoration and maintenance, it is necessary to supplement the database on the individual costs of construction elements and the duration of restoration and maintenance cycles [9].

As can be seen from the analysis, the areas of interest of researchers are very broad: from cost optimization, to the preservation of cultural and historical appearance of the city. Thus, we can say that the problem of redevelopment of cultural heritage sites today is relevant. It is considered and offer solutions to many researchers from around the world. Some of them even talk about redevelopment as a more environmentally friendly initiative, if compared with the new construction.

In their work, the authors used general scientific methods: analogy and modeling, concretization, measurement, induction.

The authors studied the world and Russian experience in the field of successful and relevant redevelopment of cultural heritage. Table 1 shows examples of successful projects of redevelopment of cultural heritage. 
Table 1. Examples of redevelopment of cultural heritage.

\begin{tabular}{|c|c|c|}
\hline $\begin{array}{l}\text { The name, country, } \\
\text { appearance before/after } \\
\text { redevelopment }\end{array}$ & Project Information & $\begin{array}{l}\text { Source of funds for } \\
\text { redevelopment }\end{array}$ \\
\hline Kunst-Werke, Berlin & $\begin{array}{l}\text { The Kunst-Werke Institute of } \\
\text { Contemporary Art is located in the } \\
\text { building of a former margarine } \\
\text { factory in the German capital city. } \\
\text { The KW Institute of Contemporary } \\
\text { Art is regularly listed among the } \\
\text { leading contemporary art } \\
\text { institutions in Germany and attracts } \\
\text { the attention of the international } \\
\text { media }\end{array}$ & $\begin{array}{l}\text { Redevelopment was } \\
\text { carried out at the expense } \\
\text { of private funds }\end{array}$ \\
\hline & $\begin{array}{l}\text { The Art Cluster was organized on } \\
\text { the site of a former abandoned } \\
\text { factory in Beijing. At present, Art } \\
\text { Zone } 798 \text { is located on an area of } \\
\text { more than } 1 \text { square kilometer }\end{array}$ & $\begin{array}{l}\text { The low cost of rent and } \\
\text { the "post-industrial } \\
\text { aesthetic" of the } \\
\text { production facilities } \\
\text { quickly enough became } \\
\text { the workplace of many } \\
\text { creative professions, who } \\
\text { independently renovated } \\
\text { the space }\end{array}$ \\
\hline & $\begin{array}{l}\text { The art quarter on the territory of } \\
\text { the cable factory in Helsinki is also } \\
\text { an object of history, which has } \\
\text { found a place in the life of modern } \\
\text { society. The public defended its } \\
\text { option of using the premises while } \\
\text { preserving its historical appearance, } \\
\text { and now the Cable Factory is } \\
\text { Europe's largest independent } \\
\text { multifunctional art and cultural } \\
\text { center (56,000 square meters). }\end{array}$ & $\begin{array}{l}\text { The space attracted the } \\
\text { creative environment } \\
\text { spontaneously: the empty } \\
\text { spaces began to be } \\
\text { occupied by clubs, } \\
\text { studios, and workshops }\end{array}$ \\
\hline $\begin{array}{c}\text { Creative Cluster } \\
\text { Russia }\end{array}$ & $\begin{array}{l}\text { The redevelopment of the Moscow- } \\
\text { Kursk Railway territory gave the } \\
\text { city a new creative cluster called } \\
\text { Arma. Since 2002, after the Arma } \\
\text { plant stopped production, } 50000 \\
\text { square meters of the total area } \\
\text { began to be rented out. Soon the } \\
\text { association Gazgolder appeared on } \\
\text { the territory of the plant, which } \\
\text { gave rise to the formation of } \\
\text { "Arma" as a creative cluster }\end{array}$ & $\begin{array}{l}\text { The renovation of the } \\
\text { buildings and the } \\
\text { landscaping of the } \\
\text { territory were done by the } \\
\text { architects of AM Sergey } \\
\text { Kiselev \& Partners, } \\
\text { mostly Vladimir Labutin } \\
\text { and Alexei Medvedev }\end{array}$ \\
\hline
\end{tabular}

\section{Results of the research}

The authors considered the international and popular at the moment development direction - presservation and redevelopment of cultural heritage objects. On the basis of international experience the authors developed a project for the redevelopment of a cultural heritage site, namely the Nurov Estate, which is located in the city of Yekaterinburg. The project was developed under the guidance of a local development company and the owner of the building - "Mayak" corporation. 
Nurov Estate is located in the historic center of Yekaterinburg. At the moment the mansion of the XIX century looks unpresentable, major repairs and restoration work in the building had not been carried out for decades. At the moment the building is used as an office building, but most of the areas are empty. Therefore redevelopment of the building is necessary. In addition, such actions will preserve the historical appearance of the city and the object of cultural heritage, as well as create a new point of attraction for citizens and tourists. It will breathe new life not only into the Nurov Estate, but may become the impetus for the redevelopment and profiling of neighbouring historic buildings.

The authors developed a concept that was to repurpose the building and create a point of attraction for people that would meet the current trends and needs of modern citizens. In the process of work to discuss plans for the redevelopment of the facility, the authors actively interacted not only with representatives of the corporation "Mayak", but also with active citizens and public organization, whose opinion was also taken into account in the formation of the project concepts [10].

The main goal of the project was to develop a redevelopment project and evaluate it in terms of investment attractiveness, as well as its sensitivity.

First of all, a detailed analysis of the surrounding area, an assessment of the actual state of the building, as well as the analysis of historical references on the site were carried out. As a result, the studied site is located in a comfortable part of the city in terms of walking and transport accessibility. The only encumbrance is the one-way traffic on the adjacent street. In addition, the problem with the lack of parking spaces is a common phenomenon in the central district.

Figure 1 shows the study of the authors, which affects the environment of the object of redevelopment (in the figure is a red circle). The area under consideration is located in the area of predominantly business development, and there are many business and business centers within walking distance. It is important to note that there are a large number of empty cultural heritage buildings around the study area, which are marked with black icons. Such spaces could be the next stage in the redevelopment of cultural heritage objects - redevelopment of the cultural quarter (further development and repurposing into points of attraction to support the creative cluster concept).

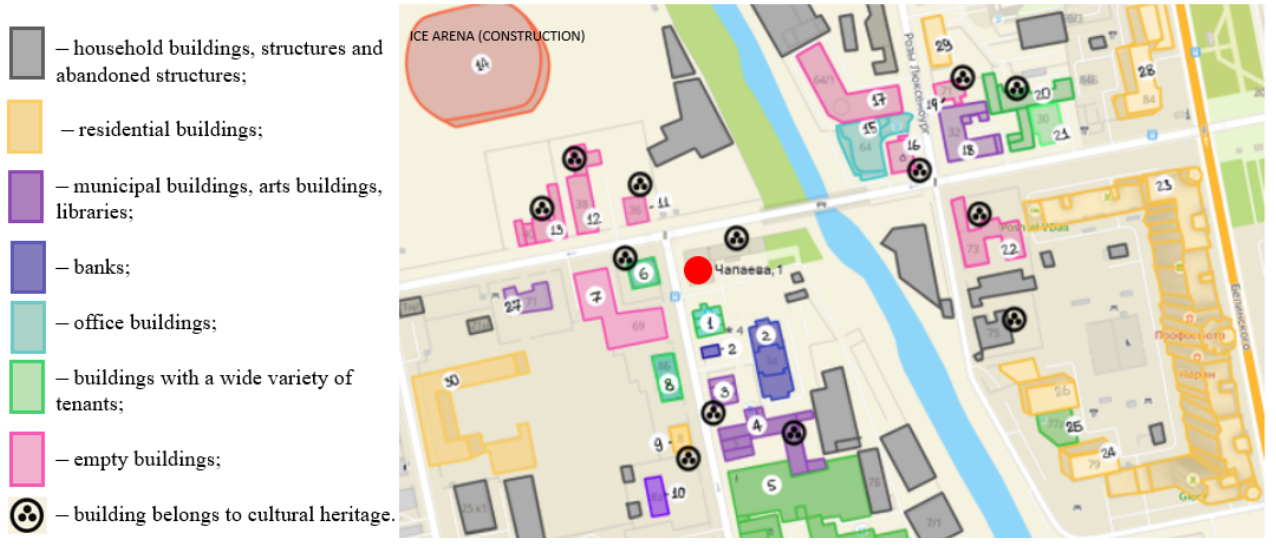

Fig. 1. The appearance of the area adjacent to the facility.

In the course of the research an unidentified structure in the Nurov's garden (presumably a greenhouse) was found in the old photographs of the site. The authors conducted research in historical archives, which resulted in finding only one similar architectural structure of the XIX century, and a similar purpose - the Tomsk University Orangery of 1880-1892 (Russia). In the photos we can see similar architectural solutions 
(pitched roof, as well as windows, which are poorly distinguishable in the photo of Nurov's garden) (Figure 2) [11].

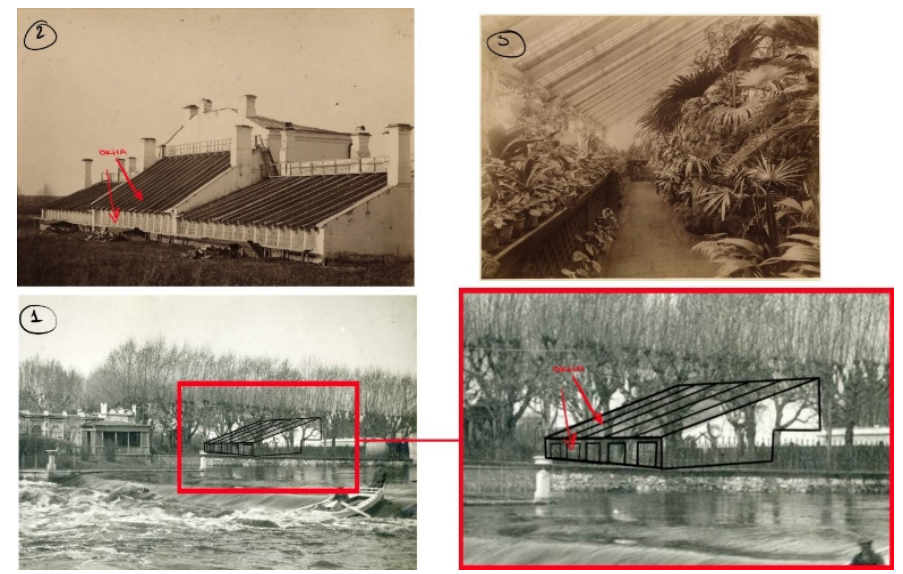

Fig. 2. Comparison of the appearance of Nurov Garden and Tomsk University.

Thus, to recreate the authentic appearance of the Nurov Estate the authors propose to erect a greenhouse, based on an analogue at Tomsk University.

The next stage of the research was the formation of the concept of re-profiling the building in the process of redevelopment works.

When working on the project, the authors also took into account the protection obligations of the cultural heritage object. In the Nurov Estate ensemble they include: angular location in the quarter; volume-planning solution of the building; architectural and decorative and color solution of the facades; multi-pitch shape of the roof; form, dimensions and location of window openings; elements of decorative decoration of the premises.

In the terms of reference for this project, provided by Lighthouse Corporation, it was prescribed that the concept of the object should be unified and have a social orientation. The company wanted to get away from the office purpose of the building, to create a new point of attraction and to revive the object, taking into account the modern needs of society. In this case, the profitability of the concept and the future purpose of the object was not a priority, the company wanted to restore the object, which is in its ownership, as well as enhance its image through the successful implementation of a social project [12].

In accordance with this, the authors analyzed current trends and needs of the population, in order to create a relevant concept and therefore the point of attraction of the area. As a result of the study, the authors found out that the city of Yekaterinburg hosts many unique festivals (Big Love Show, Ural Music Night, Unknown Film Festival, Stenograffia, etc.), various exhibitions and other creative events $[13,14]$. In addition, the city has a large number of creative studios and groups open to cooperation. However, there is a lack of a single platform where their interaction would give an effective synergetic effect. For example, photography and art studios located on the same site could organize joint activities with mutual support. This also applies to other areas of the creative professions: fashion designers, designers, musicians, dancers, etc.

Since the Nurov Estate is located in the historical center of the city and has a limited number of options for internal zoning, after the restoration it was decided to transform the area of the object into a creative Art Cluster.

The idea under consideration to create a creative cluster will allow to concentrate creative energy and direct it into business. Since there is limited space, it will be 
advantageous to place mutually complementary elements in one area for effective synergy. Creative industries (as potential tenants) include: art and culture, design, media and communications, digital technology, and education and science. Arts and culture are the most attractive for the project, as this industry includes such areas as: photography, visual and performing arts, cultural heritage, festivals and cultural initiatives, etc. For people who work in these areas it is not the office space that is important, but a creative environment that can immerse them in the creative process. It is worth bearing in mind that with a dense concentration of creative industries it is easier to gather an audience of their consumers and conduct an advertising campaign, as it is the same or similar for different creative segments.

The cluster audience can be people of all age categories, however, for a successful start of the project, the focus should be on trendsetters (people over 35 with a stable income who work in the creative industries).

Cluster space is always mobile and the main task is to keep a few anchor tenants on a permanent basis. The rest of the space can be mobile and constantly changing to meet the needs of a particular consumer, with security items not subject to change. In order to attract tenants, the following necessary elements of the Art Cluster will be taken into account (Figure 3).

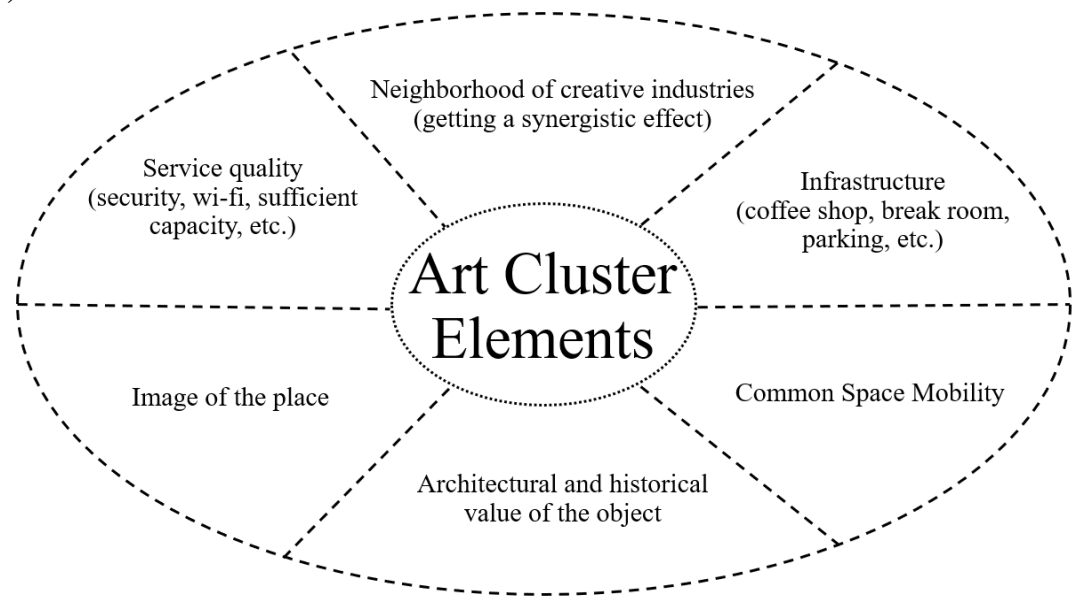

Fig. 3. Elements of the Art Cluster for the Nurov Estate.

- Neighborhood (for synergy). The interaction of creative industries is most effective when they are located in the same place, because they have the opportunity to help each other. For example, one business lends equipment to another for the duration of an event, and receives additional traffic and advertising at the event in return;

- Service quality. The presence of security, sufficient capacity to provide all residents with electricity, free internet access, creating the necessary conditions for the implementation of the eco-concept (waste sorting bins), which is a topical area, especially in the creative industries;

- Image of the place. Since the rent will be affordable for the creative industries, it is important to create a high image of the space, in which the residents could raise their status; - History of the place. The presence of the common history of the site, its architectural and historical value, unites the residents of the creative industries;

- Mobility of the shared space. Residents can create the mood of the cluster on their own, change the rented space in accordance with the established rules, and participate in the design of the common space (for example, the corridor or the entrance group) and the surrounding area; 
- 24/7 Access. Many creative processes are not limited in their working hours, as they engage in work at their convenience. Therefore, it should be left possible for the cluster to function 24/7;

- Infrastructure. Except for the design by respondents, it is necessary to improve the area, parking and provide space for 1-2 coffee shops or cafes. Consideration should also be given to organizing a common kitchen for residents with refrigerators, microwave ovens, a cooler and the necessary furniture for the comfortable operation of the cluster.

For the sustainability of the creative cluster, it is necessary to achieve the main task - to attract the creative community of the city and talented people to its space, to provide the necessary conditions for the synthesis of business ideas, production and as a result - sales of the developed product. Table 2 reveals the main tasks of the cluster.

Table 2. Main tasks of the Art Cluster.

\begin{tabular}{|c|c|c|}
\hline № & Task & Contents \\
\hline 1 & $\begin{array}{c}\text { Concentration of } \\
\text { new ideas }\end{array}$ & $\begin{array}{c}\text { It is necessary not only to attract new people, but also to retain them, to } \\
\text { provide everything necessary for work. To do this, it is necessary to } \\
\text { create conditions for comfortable and long hours }\end{array}$ \\
\hline 2 & $\begin{array}{c}\text { Creating an } \\
\text { Accelerator }\end{array}$ & $\begin{array}{c}\text { Business ideas in creative industries, like startups, must be able to be } \\
\text { implemented quickly with minimal costs, which is what the cluster } \\
\text { infrastructure helps with. Also, successful startups attract tenants and } \\
\text { consumers of the creative space }\end{array}$ \\
\hline 4 & $\begin{array}{c}\text { Creating a creative } \\
\text { product }\end{array}$ & $\begin{array}{c}\text { The development of industries requires workshops, studios, and access } \\
\text { to banking, legal, and accounting services. In a well-functioning } \\
\text { environment, respondents can adapt the space to themselves and } \\
\text { launch the production of their creative product }\end{array}$ \\
\hline 5 & $\begin{array}{c}\text { Selling the } \\
\text { product }\end{array}$ & $\begin{array}{c}\text { At this point, the main task is to organize event venues and exhibitions. } \\
\text { It is also possible to allocate an area with free access for all visitors, } \\
\text { where it will be possible to learn about the major achievements of the } \\
\text { cluster residents }\end{array}$ \\
\hline $\begin{array}{c}\text { The territory of the creative cluster can accommodate retail space, but } \\
\text { it is important to respect the terms of trade for creative products } \\
\text { without intersecting with the mass market. For example, showrooms, } \\
\text { trade lots, event venues, and events can be located on the territory of } \\
\text { the cluster. }\end{array}$ \\
\hline
\end{tabular}

Thus, the main elements of the concept-project of the Art-cluster on the territory of the Nurov Estate ensemble have been elaborated and analyzed. The project has prospects in terms of the development of public urban space, as well as a sufficient number of strengths and opportunities.

The next stage of the works was the assessment of the Nurov Estate redevelopment project from the point of view of its investment attractiveness. The main indicators of the project are given in table 3 .

Table 3. Key indicators of the Nurov Estate redevelopment project.

\begin{tabular}{|c|c|c|}
\hline Indicator & Value & Units of measure \\
\hline The total area of the Nurov ensemble & 1049 & sq. $\mathrm{m}$. \\
\hline Leasable area & 858 & sq. $\mathrm{m}$. \\
\hline
\end{tabular}


Continuation of table 3 .

\begin{tabular}{|c|c|c|} 
Estimated costs of the redevelopment project & 20712911 & rub. \\
\cline { 2 - 3 } & 24394 & rub./sq. m. \\
\hline Average rental rate & 830 & rub./sq.m./month \\
\hline \multirow{2}{*}{ Profitability of the object from the rent } & 8516709 & rub. per year \\
\cline { 2 - 3 } & 709726 & rub. per month \\
\hline
\end{tabular}

For such a project, the amount of estimated costs is satisfactory and will be accepted for further calculations of project efficiency.

In order to establish the level of rental rates, the authors analyzed the average rental rates in the central district under consideration for similar properties with a similar purpose. This rental rate includes various types of rental space for: photo studios, workshops, children's hobby groups, exhibition areas, music and art studios, and other similar uses. Lease rates have been ranked by space according to the size and intended use of the space.

The project will be financed only from Beacon Corporation's own funds, since the cost value is acceptable to the company [12].

Based on the calculations of the discount rate, taxes (land, property, VAT, profit), income from rents, the commercial efficiency of the project when using only own funds was determined (Table 4).

Table 4. Indicators of commercial effectiveness of the project.

\begin{tabular}{|c|c|c|}
\hline Indicator & Value & Units of measure \\
\hline Discount rate & 8,23 & rub \\
\hline NPV & 2097655 & $\%$ \\
\hline IRR & 10,1 & $\%$ \\
\hline $\begin{array}{c}\text { Return on investment index, } \\
\text { PI }\end{array}$ & 111,6 & years \\
\hline Simple payback period & 9,5 & years \\
\hline
\end{tabular}

Thus, the amount of money that the investor expects to receive from the project after the cash inflows will pay back his initial investment and periodic cash outflows associated with the implementation of the project Art-cluster, is 2097655 rubles.

The Art-cluster project will pay off in full in 15 years and 5 months from the start, which reflects the low efficiency of the project. It should be noted that the project has a social orientation, and Mayak Corporation does not pursue the goal of making a profit from this project. Therefore, it is recommended to accept it for further implementation.

Efficiency indicators can be improved by reducing the estimated costs (which is realistic under the conditions of this project, as the reserve fund can vary depending on the real situation related to the objects of the security obligation). 


\section{Discussion of results}

Having studied examples of implemented projects on the redevelopment of cultural heritage sites, the authors note that this direction remains relevant, which is confirmed by the desire of development companies to implement these projects, not for profit, but to create a point of attraction and social space for city residents.

Since at the moment many historical buildings are empty, deteriorating or losing their historical look and spirit of place by creating standard office premises on their territory, the authors support the ideas of Maio, Foster, Turskis and others that it is necessary to revive these objects, to attract businesses and development companies. Also, the coverage of these problems in the media, Internet space and interaction with active citizens will attract attention to these objects not only of the public and authorities, but also potential investors. These actions are necessary because the objects of cultural heritage are the historical value of each city, they reflect the spirit of the place and embody the values of the time. In addition, they can potentially become a point of attraction not only for the residents of the city, but also for tourists $[2,4,5]$.

The authors also couldn't agree more with Macek et al. that cost optimization is an important element in shaping a redevelopment project. In addition, according to the commercial efficiency of the project, the payback period and NPV reflect the low efficiency of the project. However, the redevelopment of the Nurov Estate is more of an image project for the Beacon Corporation, so it should be considered for implementation. Under such conditions, cost optimization becomes more relevant [9].

On the example of the Nurov Estate ensemble, the authors do not support Kyriazi ideas with the preservation of cultural heritage objects by means of facadism. This option is unacceptable in this case because the interior decoration of the premises belongs to the subject of protection [3].

\section{Conclusions}

In Yekaterinburg there is a large number of objects of cultural architectural heritage [15], which are in poor condition, as their restoration or redevelopment is less attractive in terms of implementation costs. However, objects of architectural and historical value can become new points of attraction of the district. The improvement of public creative spaces in this case is a good solution for the effective exploitation of the area.

This paper presents a variant of the concept project for the redevelopment of the Nurov Estate located in the central district of Yekaterinburg. Presented and described the concept of art-cluster, as a creative public and business space.

Since the estate is in poor condition, solutions for the restoration of the site were proposed, as well as the restoration of the lost historic greenhouse in the garden. The protective obligation of the site was taken into account, so the main architectural and planning solutions will be preserved in accordance with its requirements.

The authors have assessed the commercial effectiveness of the project, the results of which can be said that the project has low efficiency. However, making a profit is not the main goal of the redevelopment of this object of cultural heritage. The Mayak Corporation seeks to improve the company's image by creating a creative and relevant space. Due to the relevance and demand for creative clusters, the project is significant for the economy and public social environment of the city. As a result of the project implementation, a small Art-cluster with a multifunctional spectrum of uses for tenants will appear in the city of Yekaterinburg. 


\section{References}

1. T. Y. Bystrova, Degradation and Rehabilitation of Historical and Architectural Heritage: A functional-typological approach, Academic Vestnik UralNIIproject RAASN, 3, 26-30 (2019)

2. Z. Turskis, Z. Morkunaite, V. Kutut, A hybrid multiple criteria evaluation method of ranking of cultural heritage structures for renovation projects, International journal of strategic property management, 21 (3), 318-329 (2017)

3. E. Kyriazi, Façadism, Building Renovation and the Boundaries of Authenticity, Aesthetic Investigations, 2 (2), 184-195 (2019)

4. R. Maio, et al., Is the use of traditional seismic strengthening strategies economically attractive in the renovation of urban cultural heritage assets in Portugal? Bulletin of Earthquake Engineering, 17 (4), 2307-2330 (2019)

5. G. Foster, H. Kreinin, S. Stagl, The future of circular environmental impact indicators for cultural heritage buildings in Europe, Environmental Sciences Europe, 32 (1), 1-17 (2020)

6. G. Foster, R. Saleh, The Circular City and Adaptive Reuse of Cultural Heritage Index: Measuring the investment opportunity in Europe, Resources, Conservation and Recycling, 175, 105880 (2021)

7. M. Smol, et al, Importance of sustainable mineral resource management in implementing the circular economy (CE) model and the european green deal strategy, Resources, 9 (5), 55 (2020)

8. M. M. Sesana, et al., The ALDREN Building Renovation Passport for Non-Residential buildings: A modular digital instrument to support the Renovation Wave, REHVA European HVAC Journal, 04/2020, 35-41 (2020)

9. D. Macek, et al., Cost Optimization for Renovation and Maintenance of Cultural Heritage Objects, IOP Conference Series: Earth and Environmental Science, 290 (1) (2019)

10. Students of the Ural Federal University Institute of Economics and Technology are working on the renovation of the Nurov Estate on the assignment of the Mayak Corporation (2021). Access mode: https://gsem.urfu.ru/ru/news/35882/

11. Tomsk Imperial University 1880-1892 (2020). Access mode: https://commons.wikimedia.org/wiki/Tomsk_Imperial_University_1880-1892

12. I. Shestak, Nurov's estate will be rebuilt in Yekaterinburg. The developer will spend 100 million from his own pocket (2021). Access mode: https://www.e1.ru/text/realty/2021/07/29/70051133/

13. S. Glukhova, How many objects of cultural heritage are there in Yekaterinburg And in what condition are they (2020). Access mode: https://www.thevillage.ru/business/figures/okn-v-ekb

14. Stenograffia festival (2021). Access mode: https://stenograffia.ru/

15. L. Daineko, N. Karavaeva, I. Yurasova, Redevelopment of Ex-industrial Areas in Yekaterinburg, IOP Conference Series: Materials Science and Engineering, 1079 (3), 032093 (2021) 